\title{
Back to the Basics: Biomimicry in Shrimp Farming
}

\author{
Srijit Chakravarty $^{1 *}$, Shivendra Kumar ${ }^{1}$ and Satya Prakash ${ }^{2}$ \\ '(Aquaculture), College of Fisheries Dholi, Dr. Rajendra Prasad Central Agricultural \\ University, Samastipur, Bihar, India \\ ${ }^{2}$ ICAR-Central Institute of Fisheries Education, Rohtak Centre, Rohtak, Haryana, India \\ *Corresponding author
}

\begin{abstract}
A B S T R A C T
Keywords

Biomimicry, Copefloc, Biofloc, Shrimp, Aquamimicry, $\mathrm{C}: \mathrm{N}$ ratio

Article Info

Accepted: 18 April 2018 Available Online: 10 May 2018

Shrimp being the most valuable shellfish resource in terms of trade volume is farmed in large quantities in all South East Asian Countries including India as well as in Latin America. This industry has severely been criticized being the root cause of mangrove destruction and environment deterioration in the coastal areas due to wanton intensification and abuse of chemical and antibiotics along with discharge of untreated effluents. This has affected the shrimp farmers who suffered huge crop losses due to disease prevalence over and over again compelling them to choose a sustainable viewpoint in solidarity with the environment so that they can sustain their production systems on a longer run. Biomimicry is an approach to imitate nature and its methods of problem solving and applying those concepts in betterment of mankind. Such a concept yet novel has been introduced in shrimp farming sector too where the farmers are building copefloc instead of biofloc to stimulate the production of copepods in the system which not only acts as excellent natural food but also acts as an immunostimulant keeping the diseases at bay. This technology being superior in terms of compensation for no artificial feed requirement but production of natural feed with the help of fermented rice and soya products will definitely be the new face of shrimp farming in coming days.
\end{abstract}

\section{Introduction}

Since the past decade, the production of fish and shellfish via aquaculture practices has shown tremendous growth potential and its promise being the world's leading food producing sector has been met off lately. Shrimp farming, is one of the major aquaculture industry, especially in Asia which accounts for nearly $80 \%$ of the produce (Phillips, 1995). Globally, shrimps represent $15 \%$ of the world trade of fish and fishery products in terms of value, is ranked as second highest traded food commodity after tuna (FAO, 2016). In recent years, although global farmed shrimp production has increased to 5.7 million tons in 2010, major producing countries, in particular in Asia, has experienced a decline in output because of increased incidences of shrimp disease outbreaks (Brito et al., 2016). Owing to the rising production of shrimps, prawns, and molluscs from aquaculture and the relative decline in their price, annual per capita availability of crustaceans grew substantially from $0.4 \mathrm{~kg}$ in 1961 to $1.8 \mathrm{~kg}$ in 2013 (FAO, 
2016). This review discusses the details of problems faced by shrimp industry and recent aquamimicry techniques in vogue in shrimp farming sector.

\section{Shrimp aquaculture: genesis and problems}

When coastal aquaculture of shrimps was in its infancy, people flocked to shrimp farming in huge numbers resulting in serious concerns for the environment as In the case of the establishment, between 1 and 1.5 million hectares of coastal lowlands has been converted into shrimp aquaculture. The impact of greatest concern is the direct destruction of mangroves and marshes for shrimp pond construction (Osuna, 2001). In terms of carbon footprints, Kauffman and colleagues (2017) reported new estimates of greenhouse gas (GHG) emissions resulting from the conversion of mangrove forests into aquaculture ponds and concluded that $1603 \mathrm{~kg}$ of carbon dioxide equivalent $(\mathrm{CO} 2 \mathrm{e})$ is emitted for every kilogram of shrimp produced on lands formerly occupied by mangroves. Future predictions are even more warning as $156,480 \mathrm{~km} 2$ of mangroves would need to be converted into shrimp farms in the coming 9 years, an area larger than the current extent of existing mangrove forests worldwide $(134,300 \mathrm{~km} 2)$ (Thomas et al., 2017). Thus horizontal expansion of shrimp farming is not an option to increase production in future, rather intensification is. The most obvious curse of intensification is generation of wastes of equal proportions which needs to be treated either in-situ or ex-situ. Shrimps being extremely sensitive to impaired water quality parameters react strongly to the fallen standards of water and soil quality parameters and mortality settles in quickly.

\section{Waste management in shrimp farming}

Being a lucrative venture, farmers are resorting to Intensive shrimp farming systems, stocking up to 200,000 to $1,000,000$ pieces of shrimp post larvae per hectare ponds (20-100 pieces/sqm) within one crop, thereby generating tons of organic loads which pollutes the aquatic environment day by day and lowers the carrying capacity of the pond (Moss et al., 2001). The organic wastes in shrimp farming are quite stable Bangladesh (enriched in suspended solids, nutrients, chlorophyll an etc.), and does not have a tendency to biodegrade into simpler forms $(\mathrm{Tu}$ et al., 2008). Availability of leftover feed creates the menaces like the accumulation of undesirable organic wastes and toxic gases at the shrimp pond bottom soils and in most cases, mortality occurs when the aquaculture shrimp ponds bottom is polluted and deteriorated beyond remediating capacities of microbes (Boyd and Musing, 1992). Thus, intensification of aquaculture is self-limiting, not only because of the high cost of formulated feed, but also for its poor utilization, which causes deterioration of the pond environment and poor growth, or generates even higher costs, because of the need to increase water exchange rates (Audelo-Naranjo et al., 2017).

The idea of culturing fish in a controlled environment and expecting a predictable harvest has been one of man's endeavor since early days. However, the most recurrent problem bothering all aquaculturists is how to get sustainably deal with the problem of growing wastes in ponds and yet maintain a balanced water quality as using the chemical or biological treatments causes the alteration in the alkalinity of the water which is of prime importance for the shrimp farming (Menasveta, 2002). This problem have been approached by designing different types of ponds with advances in drainage system designs (Sandifer and Hopkins, 1992), filtration methods (Burford and Williams, 2001), in-situ bacterial digestion (Avnimelech and Ritvo, 2003), oxidation ponds (Hopkins et 
al., 1994) or recirculating ponds systems (Burford et al., 2003), yet no solution has yet been satisfactory today to correct the shrimp farming problem.

\section{Chemical abuse in shrimp farming}

As for quick relief, the shrimp farmers resort to reckless uses of chemicals either disinfectant, pesticide, oxidizing agent or antibiotics so as to address the problem on a temporary, need of the hour basis (Boyd and Massaut, 1999). However, these methods destroy the natural decomposing bacteria and benthic invertebrates to an unsuitable level so that in future, such ponds are of no use (Gräslund and Bengtsson, 2001). Mostly the farmers use chlorine, formalin, quaternary ammonium compounds, iodophores and hydrogen peroxide as disinfectants as well as antibiotics like fluoroquinolones, tetracyclines, and sulfonamides which exerts nonselective killing of the soil conditioning microbes involved in nutrient cycling and release (Gräslund et al., 2003). Such wanton use of pesticides and chemicals also possess a threat to the consumers as mostly the chemicals are bioaccumulated in these crustaceans and get into the digestive system of consumers and interfere with the body physiology and homeostasis (Holmström et al., 2003).

\section{Disease outbreaks in shrimp aquaculture}

Despite the quantum leap in production in the last decade, the rising graph of shrimp production has been severely punctuated by diseases, especially the White Spot Syndrome Virus causing heavy mortalities in the South east Asian countries (Lightner, 1999), Taura Syndrome Virus in Ecuador (Brock et al., 1997), the outbreak of Infectious Myonecrosis Virus in northeast Brazil (Lightner and Pantoja, 2004) and more recently, yellow head virus (YHV) (Senapin et al., 2010) that causes yellow head disease (YHD), Early mortality syndrome (EMS) or acute hepatopancreatic necrosis disease (AHPND) outbreak in China, Thailand, Vietnam and Mexico (Joshi et al., 2014; Nunan et al., 2014; Soto-Rodriguez et al., 2015), hepatopancreatic microsporidiosis (HPM), hepatopancreatic haplosporidiosis $(\mathrm{HPH})$, aggregated transformed microvilli (ATM) and covert mortality disease (CMD) in South east Asian countries (Thitamadee et al., 2016). A summary of recent diseases in aquaculture has been given in Table 1. As a result, global shrimp prices have fallen significantly year-on-year, after reaching a record high in 2014. In the first half of 2015, shrimp prices plummeted by 15-20 percent compared with the first half of 2014, Thailand has experienced a substantial decline in exports since 2013, mainly linked to reduced shrimp production due to disease problems (FAO, 2016).

Myriad varieties of prophylactic measures have been applied for preventing such disease problems in shrimp aquaculture sector such as use of SPF (specific pathogen free) stock (Lotz et al., 1997), adopting better management practices (Tucker and Hargreaves, 2009), applying biosecurity measures and routine surveillance (Lightner, 2005), zero water exchange techniques (Wasielesky et al., 2006) etc. Common factors associated with disease include rapid expansion of the industry, lack of environmental control, increased regional incidence of disease, use of non SPF seeds, noncompliance to biosecurity measures and many more (Browdy and Hopkins, 1995; Flegel and Alday- Sanz, 1998; BondadReantaso et al., 2005; Thitamadee et al., 2016)

It is a well-documented fact that Zero exchange pond production reduces the risk of introduction and spread of disease while providing the nutritional benefits of natural productivity within ponds (Moss et al., 2001; 
Burford et al., 2003; Wasielesky et al., 2006 Samocha et al., 2007). Some of the highest production levels have been achieved in very low exchange systems based on suspended microbial floc communities. Browdy et al., (2001) reported an average production of 15 tons/ha in these types of ponds in Belize. Although high levels of productivity can be achieved in open ponds, production is limited to one or two crops/year in most temperate to tropical locations (Tidwell et al., 2003) and biosecurity remains an important concern (Weirich et al., 2003).

\section{Biomimicry in shrimp farming: the road to sustainability}

Biomimicry is a revolutionary new science that uses our scientific understanding of biological systems to exploit the best ideas from nature in order to construct some technology so that they can be put induces positive outcomes in human lives (Benyus, 2002). It's what our ancestors have been following since ages but in the light of modern scientific findings and quantifiable results. Since its advent, it has been applied to various sectors like architecture to build earthquake tolerant buildings (Pawlyn, 2011), bioprocessing (Passino, 2002), bioengineering, for building organs on microchips (Huh et al., 2012).

According to Benyus, nine principles can be identified as underlying nature's designs. Nature, she argues, (i) runs on sunlight, (ii) uses only the energy it needs, (iii) fits form to function, (iv) recycles everything, (v) rewards cooperation, (vi) banks on diversity, (vii) demands local expertise, (viii) curbs excesses from within, and (ix) taps the power of limits (Benyus, 2002). If we design our industry and our built environment in accordance with these principles, Benyus suggests, we would be well on the way to living within the ecological limits of nature and thus achieving our goal of sustainability. It is noteworthy that, the total biomass of ants on earth is greater than the total biomass of humans, yet no pollution or ecological degradation results from their activities as their activities feedback nutritiously into the ecosystems that support them (McDonough, 2002). He further opines that not curbing the production, but redesigning of methods of production, so that it regenerates nature rather than depleting and degrading it, is the solution to meet future sustainability goals.

Recent disease outbreaks have severely jolted the skyrocketing momentum of the shrimp industry and as the investigations have revealed, a majority of the present day diseases are caused due to improper water quality management at the farm level, pushing the productivity to critical limits until they crash. As a result, many aquaculturists have resorted to low stocking density based extensive (organic) farming methods to replenish the lost nutrients from the pond soil naturally within the production system (Paul and Vogl, 2011). Products of such systems claim a premium price of the product as a compensation for quantitative loss over the conventional farmers. This has paved the way for the generation of a greener alternative to ameliorate wastes in the shrimp ponds and keeping environmental sustainability a top priority in the farming activities. Such systems as a whole come under the purview of bio/ aquamimicry which emphasizes the natural remediation techniques of the ecosystems by promoting the natural cycling of minerals and production of live feed organisms (Romano and Kumar, 2017).

\section{Biofloc: understanding the $\mathrm{C}: \mathrm{N}$ ratio}

Aquaculture is the fastest growing foodproducing sector offers ample opportunities to address the problem of nutritional insecurity of feeding the 9 billion population by 2050 as 
with an annual growth rate of $5.8 \%$, this sector is projected to rise from 73.8 million tonnes in 2014 to over 85 million tonnes in 2050 (FAO, 2016). Fish being the most efficient converter of energy derived from feed into muscle protein will need more and more amount of inputs in future in terms of feed and fertilizers (Béné et al., 2015). The nutrient waste in an aquaculture system is mostly generated from unconsumed feed and the digestion and metabolic processes of feed (Bossier and Ekasari, 2017). This unconsumed feed accumulates in the pond bottoms and gives rise to toxic metabolites like ammonia, methane, $\mathrm{H}_{2} \mathrm{~S}$ etc. Waste assimilation in shrimp farming during the cycle of operation is solely done by the soil microbes which operate the biogeochemical cycles for nutrient recycling. As the intensity of production is increasing day by day, the natural cycling of nutrients is becoming incompetent unless they receive some supplementation in form of external inputs (Béné et al., 2015).

The heterotrophic microbes require a balanced Carbon: Nitrogen $(\mathrm{C}: \mathrm{N})$ ratio for their growth and functioning which should ideally be between 10:1 and 20:1 (Asaduzzaman et al., 2010). Biofloc technology was conceptualized for in-situ waste amelioration by the heterotrophic microbial community stimulated by the addition of any low-cost carbon source like bagasse, molasses etc. The goal is to balance the $\mathrm{C}$ : $\mathrm{N}$ ratio within the desirable range where the bacteria derive the carbon from the supplied source and nitrogen from the fecal or detrital matter. Bacteria have to produce protein for their growth. If the substrate is mostly carbonaceous, they need to take nitrogen from the water and thereby the toxic nitrogenous metabolites like ammonia are converted into microbial protein in this system (Avnimelech, 2009). Thus it provides the most cost-effective method for the waste assimilation in intensively stocked shrimp ponds (Crab et al., 2012). Furthermore, use of substrates and manipulation of $\mathrm{C}: \mathrm{N}$ ratio in freshwater finfish and prawn production by addition of carbon source in extensive ponds have been found promising in resource-poor countries like Bangladesh. In addition to waste management, the flocs grew also serve as shelter to minimize territorial effects and improved water quality through trapping suspended solids, organic matter breakdown and enhanced nitrification in case of Macrobrachium rosenbergii (Asaduzzaman et al., 2008). Apart from waste assimilation the microbial flocs also offer themselves as live feed aggregates for the stocked fishes lowering the feed cost up to a certain extent (Avnimelech, 2009). The biofloc is an assemblage of more than 750 OTUs (Operational Taxonomic units) microbiotas (Kim et al., 2014). The diverse microbiota prevents the domination of any singular pathogenic species. Some of these microbiotas are also able to elicit the non-specific immune response of the shrimp (Thong, 2014)

\section{From biofloc to copefloc}

Biofloc technology being the need of the hour as a all-in-one solution for in-situ waste management in shrimp ponds has some disadvantages too which deters the shrimp farmers in using this. The first drawback of the biofloc system is that it requires constant aeration to keep the wastes in suspension for proper degradation which adds up to the production cost (Romano and Kumar 2017). As in intensive farming systems, improper positioning of aerators also induces a strong water current which has pronounced negative effect on the pond dyke structures lowering their structural integrity (Crab et al., 2012). Secondly, the drop in $\mathrm{pH}$ and alkalinity due to nitrification and the need to add sufficient carbon are all factors that need to be monitored closely compared with conventional methods of shrimp farming (Thong, 2014). 
Table.1 Chronological summary of major diseases affecting shrimp farming

\begin{tabular}{|c|c|c|c|c|}
\hline Disease name & $\begin{array}{l}\text { Causative } \\
\text { organism }\end{array}$ & $\begin{array}{l}\text { Life stage } \\
\text { affected }\end{array}$ & $\begin{array}{l}\text { Year and } \\
\text { Place of } \\
\text { occurrence }\end{array}$ & $\begin{array}{c}\text { Reference citing first } \\
\text { report / causative } \\
\text { organism }\end{array}$ \\
\hline $\begin{array}{l}\text { Baculovirus } \\
\text { penaei disease } \\
\end{array}$ & $\begin{array}{l}\text { Baculovirus } \\
\text { penaei (BP) }\end{array}$ & $\mathrm{J}, \mathrm{PL}, \mathrm{A}$ & $\begin{array}{c}\text { South America, } \\
1974\end{array}$ & $\begin{array}{l}\text { Couch } \\
(1974)\end{array}$ \\
\hline $\begin{array}{l}\text { Monodon } \\
\text { baculovirus } \\
\text { disease }\end{array}$ & $\begin{array}{l}\text { Monodon } \\
\text { baculovirus } \\
(\mathrm{MBV})\end{array}$ & $\mathrm{J}, \mathrm{PL}, \mathrm{A}$ & Taiwan, 1981 & $\begin{array}{l}\text { Lightner and Redman } \\
\text { (1981) }\end{array}$ \\
\hline $\begin{array}{l}\text { Infectious } \\
\text { hypodermal } \\
\text { and } \\
\text { hematopoietic } \\
\text { necrosis/ Runt } \\
\text { deformity } \\
\text { Syndrome }\end{array}$ & $\begin{array}{l}\text { Infectious } \\
\text { hypodermal and } \\
\text { hematopoietic } \\
\text { necrosis virus } \\
\text { (IHHNV) }\end{array}$ & $\mathrm{J}, \mathrm{PL}, \mathrm{A}$ & $\begin{array}{c}\text { South America, } \\
1983\end{array}$ & $\begin{array}{l}\text { Lightner et al., } \\
\text { (1983) }\end{array}$ \\
\hline $\begin{array}{l}\text { Hepatopancrea } \\
\text { tic } \\
\text { parvo-like } \\
\text { virus disease } \\
\end{array}$ & $\begin{array}{l}\text { Hepatopancreatic } \\
\text { parvo-like virus } \\
(\mathrm{HPV}),\end{array}$ & J, PL, A & China, 1985 & Mari et al., (1993) \\
\hline $\begin{array}{l}\text { Yellow head } \\
\text { disease }\end{array}$ & $\begin{array}{l}\text { Yellow head } \\
\text { virus }\end{array}$ & $\mathrm{J}, \mathrm{PL}, \mathrm{A}$ & Thailand, 1990 & $\begin{array}{l}\text { Boonyaratpalin et al., } \\
\text { (1993) }\end{array}$ \\
\hline $\begin{array}{l}\text { Taura } \\
\text { syndrome } \\
\text { disease } \\
\end{array}$ & $\begin{array}{l}\text { Taura syndrome } \\
\text { virus (TSV) }\end{array}$ & $\mathrm{J}, \mathrm{PL}, \mathrm{A}$ & Ecuador, 1992 & Bonami et al., (1997) \\
\hline $\begin{array}{l}\text { White Spot } \\
\text { Syndrome } \\
\text { Virus Disease }\end{array}$ & $\begin{array}{l}\text { Whites spot } \\
\text { shrimp virus }\end{array}$ & J, PL, A & $\begin{array}{l}\text { South east } \\
\text { Asia, } 1994\end{array}$ & Durand et al., (1997) \\
\hline $\begin{array}{l}\text { Monodon slow } \\
\text { growth } \\
\text { Syndrome } \\
\end{array}$ & $\begin{array}{l}\text { Laem Singh virus } \\
\text { (LSNV) }\end{array}$ & J, PL, A & Thailand, 2001 & $\begin{array}{l}\text { Sritunyalucksana et } \\
\text { al., (2006) }\end{array}$ \\
\hline $\begin{array}{l}\text { Hepatopancrea } \\
\text { tic } \\
\text { microsporidios } \\
\text { is (HPM) }\end{array}$ & $\begin{array}{l}\text { Enterocytozoon } \\
\text { hepatopenaei }\end{array}$ & J, PL, A & Thailand, 2004 & $\begin{array}{l}\text { Chayaburakul et al., } \\
\text { (2004) }\end{array}$ \\
\hline $\begin{array}{l}\text { Early mortality } \\
\text { syndrome }\end{array}$ & $\begin{array}{l}\text { Vibrio } \\
\text { parahaemolyticus } \\
\left(\text { VP }_{\text {AHPND }}\right)\end{array}$ & $\mathrm{J}, \mathrm{PL}$ & China, 2009 & $\begin{array}{l}\text { Lightner et al., } \\
\text { (2012); NACA (2012) }\end{array}$ \\
\hline $\begin{array}{l}\text { Running } \\
\text { mortality } \\
\text { syndrome }\end{array}$ & $\begin{array}{l}\text { Water quality } \\
\text { deterioration }\end{array}$ & $\mathrm{J}, \mathrm{PL}$ & India, 2016 & Mastan et al., (2016) \\
\hline
\end{tabular}

$\mathrm{J}=$ Juvenile; $\mathrm{PL}=$ Post larva; $\mathrm{A}=$ Adult 
Fig.1 The process of development of copefloc in shrimp farm and aquamimicry based shrimp farming

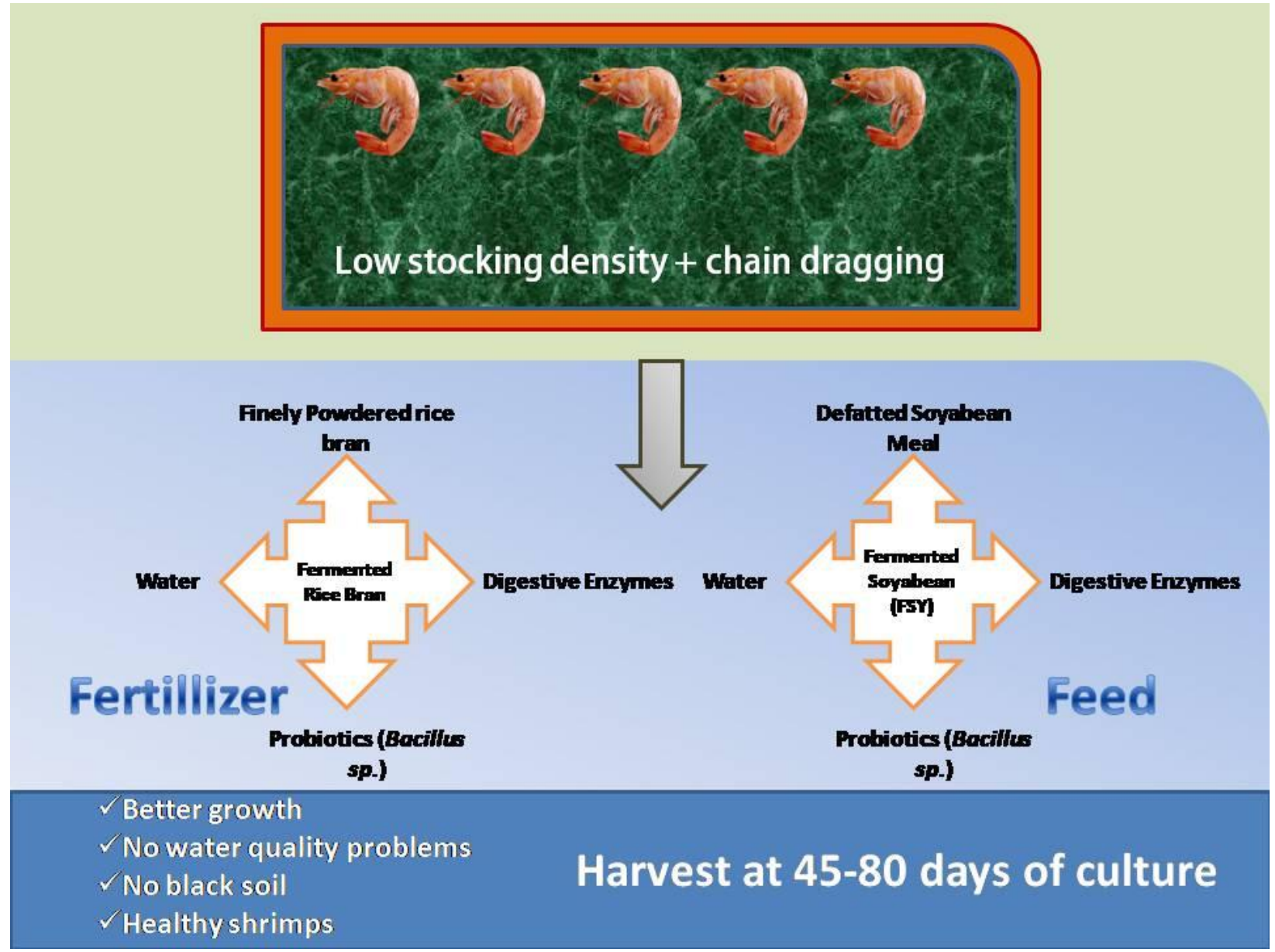

Considering these loopholes a novel technology called the copefloc technology has been initiated in the shrimp farming community which negates the use of feed or any oxygenation in the ponds rather relies on the natural production of copepods, for the feeding of the stocked shrimps (Romano and Kumar, 2017).

The zooplankton copepod lives in fresh, salt and brackish water all around the world. Due to their short lives of one year, these tiny crustaceans have many uses in nature viz., food for marine animals, nutrient recyclers and converts energy in the food chain (Christenson, 2016). The use of copepods has intensified in the shrimp farming sector, owing to their better biochemical composition (Drillet et al., 2006), improvement in survival rate and growth (Rajkumar and Vasagam, 2006), ability to reduce post mortem malpigmentation (Shields et al., 1999).

The relevant candidate species of copepods for aquaculture belong to three orders viz., Harpacticoid, calanoid and cyclopoid (Støttrup, 2006). Harpacticoid copepods are epi-benthic copepods and have superior nutritional attributes compared to Artemia and rotifers (Drillet et al., 2006). The best advantage of the harpacticoids is that they can be grown at high densities (e.g. from 10,000 to 400,000/L, (Støttrup, 2003). However, being egg carriers, the harvest of nauplii is 
difficult in large systems. Cyclopoid copepods are pelagic and are used occasionally in aquaculture and densities of $\sim 5000 / \mathrm{L}$ are possible to achieve in cultures (Phelps et al., 2005; Su et al., 2005). In spite of their promising nutritional profile their culture is still not in vogue because of the difficulties in harvesting nauplii from culture and in the lack of storage possibilities for eggs (Støttrup, 2006). Calanoid copepods are pelagic and are the natural prey for fish larvae (Drillet et al., 2011). Several calanoid copepod species have been proposed as candidates for aquaculture production; and the commonly studied species are from the following genera Acartia, Eurytemora, Gladioferens, Parvocalanus, and Centropages (O'Bryen and Lee, 2005).

Aquamimicry is the most recent concept of in-situ waste assimilation within shrimp ponds where the production of zooplankton (particularly copepods) is stimulated by using carbohydrate sources like fermented rice bran (FRB). The process of making and using the FRB as per Nicholas and Romano (2017) is described here. FRB is made by adding water and probiotics and hydrolyzing enzymes to finely grounded rice bran powder allowed to soak overnight, and is applied at a rate 500$1000 \mathrm{~kg} / \mathrm{Ha}$ in ponds 24 hours after the fermentation process is over. Within a week of the application of this mixture, the dominance of copepods can be seen in the pond water. As soon as the copepod bloom is ready, the post larvae of the shrimps are added to the pond at a much lesser stocking density (usually 10-20 individuals/ $\mathrm{m}^{2}$ ) compared to that used for intensive farming. The stocked ponds are routinely seeded with FRB at a rate of $10 \mathrm{~kg} / \mathrm{Ha}$ every month to sustain the copepod bloom. In addition to creating the biofloc (or copefloc so to say) it also provides supplementary nutrition to the stocked shrimps as they feed on the particles of FRB very easily. The harvest is generally done at 45-80 days, depending on the size desired at harvest.

The biggest advantage of this system is that this can partially/ totally negate the use of commercial feed in the culture which accounts for $\sim 60-70 \%$ of the production cost. For feeding, Fermented Soyabean (FSY) composed of defatted soyabean meal along with some different carbohydrate sources like wheat and rice bran and other probiotics are used. This feed and fertilization using FSY and FRB not only makes the shrimps healthy, improves their appetite, but also obliterates the production of black soil and subsequent deterioration in water quality due to build up toxic metabolites in the system. Also, there is no need to provide aeration in the system unlike biofloc as the target organism is not bacteria but the copepods (Nicholas and Romano, 2017). A pictorial representation of the entire process is given in Figure 1.

Thus, aquamimicry based shrimp farming can keep the shrimps healthy, the diseases at bay and pave way for the sustainable shrimp farming. The shrimps produced in such a way are devoid of any harmful residues like chemicals or antibiotics and thereby fetch a premium price in the market. According to some consumers, they even taste better than those produced via using unsustainable means (Higuchi, 2017; Nicholas and Romano, 2017)

\section{Diversification via synergy: Mussels as bioremediation agent in shrimp farms}

It is a well-known fact the physical, chemical and biological conditions of the culture environment have a profound influence on the health and productivity of the cultured shrimp (Boyd and Musing, 1992). Exposure of shrimps to such adversities lead to stress which culminates in various infectious as well as non-infectious disease jeopardizing the culture. It is arguably true that aquaculture 
wastes, like total suspended solids (TSS) and organic suspended solids (OSS), have a negative impact on the environment, causing ecological imbalances (Martínez-Córdova et al., 2009).

A potent method of waste management uses the filter feeding bivalves and gastropods for bioremediation approaches. This not only improves the hygiene of the pond, but also diversifies the produce so that in case the primary crop failure occurs, a backup is present to bolster the economic losses incurred (Rawson et al.,2002, Peharda et al., 2007). Jones and Preston (2001) found that the shrimp effluent was an adequate environment in which bivalve mollusk can thrive well.

In Crassostrea virginica culture, Jakob et al., (1993) reported that the use of shrimp-pond effluent fulfills all the nutritional requirements for that species. It is also reported that nutritional value of cultured microalgae, Skeletonema costatum, and shrimp effluent as food sources for the Pacific oyster, Crassostrea gigas, not finding significant differences between both sources Lefebvre et al., (2000). Several other commercially important bivalves, e.g., Anadara grandis, A. tuberculosa, Crassostrea corteziensi has been reported for having excellent bioremediation properties for the shrimp effluents (Miranda-Baeza et al., 2006, Wilber et al.,2006, Peña-Messina et al., 2009). The high survival of clams after the trial, suggests that the shrimp pond effluent may be an acceptable environment for the growth of the species, especially at the lower density $\left(12.5 / \mathrm{m}^{2}\right)$ where a survival of $85 \%$ was observed by Martínez-Córdova et al., (2011). Such findings suggest that clams can be an excellent synergistic species for the shrimp farming imitating the natural habitat of shrimp culture.
Wanton use of chemical and antibiotics have let to widespread damage to the environment and the spread of various diseases have led to crop failure and reduced production of shrimp culture in several countries including India. To solve these problems, we need an ecological approach in the shrimp culture technology or in other words eco-friendly shrimp culture (environmentally friendly) with waste utilization as optimal as possible. Biomimicry refers to the use of ideas inspired from nature for solving the problems faced by the humanity and thereby mimicking the natural environment to boost productivity in shrimp farming has shown encouraging results among the practitioners in South east Asia. This inculcates the use of fermented rice bran and soybean for feed and fertilization purposes so that there is no unconsumed feed and if any, it is easily biodegradable. This practices also prophesize keeping the stocking density of the pond lower than intensive farming systems so that there is less feed wastage and build up of toxic wastes in the systems. This technology, though in its nascent stages will definitely prove worthwhile in the era of sustainable shrimp farming and copeflocs will soon replace bioflocs in intensive farming systems too where it can be utilized for getting maximum output without jeopardizing the natural regenerative capacity of the soil fertility.

\section{References}

Antony, S. P., and Philip, R., 2006. Bioremediation in shrimp culture systems. Naga The World Fish Center Quarterly, 29(3 and 4), 62-66.

Asaduzzaman, M., Rahman, M. M., Azim, M. E., Islam, M. A., Wahab, M. A., M. C. J., Verdegem, and Verreth, J. A. J., 2010. Effects of $\mathrm{C} / \mathrm{N}$ ratio and substrate addition on natural food communities in freshwater prawn monoculture ponds. Aquaculture, 306 (1-4), 127-136.

Asaduzzaman, M., Wahab, M. A., Verdegem, M. C. J., Huque, S., M. A., Salam, and Azim, 
M. E., 2008. C/N ratio control and substrate addition for periphyton development jointly enhance freshwater prawn Macrobrachium rosenbergii production in ponds. Aquaculture, 280(1-4), 117-123.

Audelo-Naranjo, J. M., Martínez-Córdova, L. R., S. Gómez-Jiménez, and Voltolina, D., 2017. Intensive culture of Litopenaeus vannamei without water exchange and with an artificial substrate. Hidrobiológica, 22(1), 1-7.

Avnimelech, Y., 2009. Biofloc technology. A practical guide book. The World Aquaculture Society, Baton Rouge, 182.

Avnimelech, Y., and Ritvo, G., 2003. Shrimp and fish pond soils: processes and management. Aquaculture, 220(1-4), 549-567.

Béné, C., Barange, M., Subasinghe, R., PinstrupAndersen, P., Merino, G., G. I. Hemre, and Williams, M., 2015. Feeding 9 billion by 2050-Putting fish back on the menu. Food Security, 7(2), 261-274.

Benyus, J. M., 2002. Biomimicry: Innovation inspired by nature. Harper Perennial. Pp 320.

Bonami, J.R., Hasson, K.W., Mari, J., B.T. Poulos, and Lightner, D.V., 1997. Taura syndrome of marine penaeid shrimp: characterization of the viral agent. Journal of General Virology, 78(2), pp.313-319.

Bondad-Reantaso, M. G., Subasinghe, R. P., Arthur, J. R., Ogawa, K., Chinabut, S., Adlard, R., and Shariff, M., 2005. Disease and health management in Asian aquaculture. Veterinary Parasitology, 132(3-4), 249-272.

Boone Kauffman, J., Arifanti, V. B., Hernández Trejo, H., Carmen Jesús García, M., Norfolk, J., Cifuentes, M., and Murdiyarso, D. 2017. The jumbo carbon footprint of a shrimp: carbon losses from mangrove deforestation. Frontiers in Ecology and the Environment, 15(4), 183-188.

Boonyaratpalin, S., Supamattaya, K., Kasornchandra, J., Direkbusaracom, S., U. Aekpanithanpong, and Chantanachooklin, C., 1993. Non-occluded baculo-like virus, the causative agent of yellow head disease in the black tiger shrimp (Penaeus monodon). Fish Pathology, 28(3), pp.103109.
Boyd, C. E., and Massaut, L., 1999. Risks associated with the use of chemicals in pond aquaculture. Aquacultural Engineering, 20(2), 113-132.

Boyd, C. E., and Musig, Y., 1992. Shrimp pond effluents: observations of the nature of the problem on commercial farms. In Proceedings of the special session on shrimp farming (pp. 195-197). World Aquaculture Society Baton Rouge, LA.

Brito, C., Valle, B., Interaminense, J., Peixoto, S., J. V. Lima- Filho and Soares, R. 2016., Microbiological quality of Litopenaeus vannamei culture using conventional and biofloc systems. Aquaculture research, 47(10), 3098-3108.

Brock, J. A., 1997. Taura syndrome, a disease important to shrimp farms in the Americas. World Journal of Microbiology and Biotechnology, 13(4), 415-418.

Browdy, C. L., Bratvold, D., A. D. Stokes, and McIntosh, R. P., 2001. Perspectives on the application of closed shrimp culture systems. In The New Wave, Proceedings of the Special Session on Sustainable Shrimp Culture, Aquaculture 2001 (pp. 20-34). The World Aquaculture Society Baton Rouge, USA.

Burford, M. A., and Williams, K. C., 2001. The fate of nitrogenous waste from shrimp feeding. Aquaculture, 198(1-2), 79-93.

Burford, M. A., Thompson, P. J., McIntosh, R. P., R. H. Bauman, and Pearson, D. C., 2003. Nutrient and microbial dynamics in highintensity, zero-exchange shrimp ponds in Belize. Aquaculture, 219(1-4), 393-411.

Burford, M. A., Thompson, P. J., McIntosh, R. P., R. H. Bauman, and Pearson, D. C., 2003. Nutrient and microbial dynamics in highintensity, zero-exchange shrimp ponds in Belize. Aquaculture, 219(1-4), 393-411.

Chayaburakul, K., Nash, G., Pratanpipat, P., S. Sriurairatana, and Withyachumnarnkul, B., 2004. Multiple pathogens found in growthretarded black tiger shrimp Penaeus monodon cultivated in Thailand. Diseases of aquatic organisms, 60(2), pp.89-96.

Christenson, L. H., 2016. Hoppkräftor (Copepoda) som föda till djur och människor.

Couch, J.A., 1974. An enzootic nuclear polyhedrosis virus of pink shrimp: 
ultrastructure, prevalence, and enhancement. Journal of Invertebrate Pathology, 24(3), pp.311-331.

Crab, R., Defoirdt, T., P. Bossier, and Verstraete, W., 2012. Biofloc technology in aquaculture: beneficial effects and future challenges. Aquaculture, 356, 351-356.

Drillet, G., Jørgensen, N. O., Sørensen, T. F., H. Ramløv, and Hansen, B. W., 2006. Biochemical and technical observations supporting the use of copepods as live feed organisms in marine larviculture. Aquaculture Research, 37(8), 756-772.

Durand, S., Lightner, D.V., Redman, R.M. and Bonami, J.R., 1997. Ultrastructure and morphogenesis of white spot syndrome baculovirus (WSSV). Diseases of Aquatic Organisms, 29(3), pp.205-211.

FAO, 2016. The State of World Fisheries and Aquaculture 2016. Contributing to food security and nutrition for all. Rome. $200 \mathrm{pp}$.

Flegel, T. W., and Alday- Sanz, V., 1998. The crisis in Asian shrimp aquaculture: current status and future needs. Journal of Applied Ichthyology, 14(3- 4), 269-273.

Gräslund, S., and Bengtsson, B. E., 2001. Chemicals and biological products used in south-east Asian shrimp farming, and their potential impact on the environment-a review. Science of the Total Environment, 280(1-3), 93-131.

Higuchi, A., 2017. Purchasing factors of organic consumers in the metropolitan area of Lima, Peru.

Holmström, K., Gräslund, S., Wahlström, A., Poungshompoo, S., B. E. Bengtsson and Kautsky, N., 2003. Antibiotic use in shrimp farming and implications for environmental impacts and human health. International journal of food science and technology, 38(3), 255-266.

Hopkins, J. S., P. A. Sandifer, and Browdy, C. L., 1994. Sludge management in intensive pond culture of shrimp: effect of management regime on water quality, sludge characteristics, nitrogen extinction, and shrimp production. Aquacultural Engineering, 13(1), 11-30.

Huh, D., Torisawa, Y. S., Hamilton, G. A., H. J. Kim, and Ingber, D. E., 2012. Microengineered physiological biomimicry: organs-on-chips. Lab on a Chip, 12(12), 2156-2164.

Joshi, J., Srisala, J., Truong, V. H., Chen, I. T., Nuangsaeng, B., Suthienkul, O., and Thitamadee, S., 2014. Variation in Vibrio parahaemolyticus isolates from a single Thai shrimp farm experiencing an outbreak of acute hepatopancreatic necrosis disease (AHPND). Aquaculture, 428, 297-302.

Kim, S. K., Pang, Z., Seo, H. C., Cho, Y. R., T. Samocha, and Jang, I. K., 2014. Effect of bioflocs on growth and immune activity of Pacific white shrimp, Litopenaeus vannamei postlarvae. Aquaculture Research, 45(2), 362-371.

Lightner, D. V., 1999. The penaeid shrimp viruses TSV, IHHNV, WSSV, and YHV: current status in the Americas, available diagnostic methods, and management strategies. Journal of Applied Aquaculture, 9(2), 2752.

Lightner, D. V., 2005. Biosecurity in shrimp farming: pathogen exclusion through use of SPF stock and routine surveillance. Journal of the World Aquaculture Society, 36(3), 229-248.

Lightner, D. V., Pantoja, C. R., Poulos, B. T., Tang, K. F. J., Redman, R. M., P. D., Andrade and Bonami, J. R., 2004. Infectious myonecrosis: new disease in Pacific white shrimp. Glob Aquac Advocate, 7, 85.

Lightner, D.V. and Redman, R.M., 1981. A baculovirus-caused disease of the penaeid shrimp, Penaeus monodon. Journal of invertebrate pathology, 38(2), pp.299-302.

Lightner, D.V., Redman, R.M., Pantoja, C., B. L. Noble, and Tran, L., 2012. Early mortality syndrome affects shrimp in Asia. Glob. Aquac. Advocate (Jan-Feb, 40).

Lotz, J. M., 1997. Viruses, biosecurity and specific pathogen-free stocks in shrimp aquaculture. World Journal of Microbiology and Biotechnology, 13(4), 405-413.

Mari, J., Bonami, J.R. and Lightner, D., 1993. Partial cloning of the genome of infectious hypodermal and haematopoietic necrosis virus, an unusual parvovirus pathogenic for penaeid shrimps; diagnosis of the disease 
using a specific probe. Journal of general virology, 74(12), pp.2637-2643.

Martínez-Córdova, L. R., López-Elías, J. A., Martínez-Porchas, M., T. Bernal-Jaspeado, and Miranda-Baeza, A., 2011. Studies on the bioremediation capacity of the adult black clam, Chione fluctifraga, of shrimp culture effluents. Revista de Biología Marina y Oceanografía, 46(1).

Mastan, S.A. and Ahmed, M.O., 2016. Running mortality syndrome (RMS) in farm-reared shrimp, Litopenaeus vannamei culture systems in Andhra Pradesh, India. Indo American Journal of Pharmaceutical Research.

McDonough, W., 2002. Cradle to Cradle: Remaking the way we make things. New York, NY: North Point Press.

Menasveta, P., 2002. Improved shrimp grow out systems for disease prevention and environmental sustainability in Asia. Reviews in Fisheries Science, 10(3-4), 391402.

Miranda-Baeza A, D Voltolina and CorderoEzquivel B., 2006. Filtration and clearence rates of Anadara grandis juveniles (Pelecypoda, Aricidae) with different temperatures and suspended matter concentrations. Revista de Biología Tropical 54: 787-792

Moss, S. M., Arce, S. M., Argue, B. J., Otoshi, C. A., F. R. Calderon, and Tacon, A. G. 2001. Greening of the blue revolution: efforts toward environmentally responsible shrimp culture. In The New Wave, Proceedings of the special session on sustainable shrimp culture, aquaculture (pp. 1-19).

Moss, S. M., Divakaran, S., and Kim, B. G. (2001). Stimulating effects of pond water on digestive enzyme activity in the Pacific white shrimp, Litopenaeus vannamei (Boone). Aquaculture Research, 32(2), 125131.

NACA, 2012. Report of the Asia Pacific Emergency Regional Consultation on the Emerging Shrimp Disease: Early Mortality Syndrome (EMS)/Acute Hepatopancreatic Necrosis Syndrome (AHPNS), 9-10 August, Bangkok, Thailand. Network of Aquacultue Centres in Asia-Pacific (NACA) (www.enaca.org).
Nunan, L., Lightner, D., C. Pantoja, and GomezJimenez, S., 2014. Detection of acute hepatopancreatic necrosis disease (AHPND) in Mexico. Diseases of aquatic organisms, 111(1), 81-86.

Páez-Osuna, F., 2001. The environmental impact of shrimp aquaculture: a global perspective. Environmental pollution, 112(2), 229-231.

Passino, K. M., 2002. Biomimicry of bacterial foraging for distributed optimization and control. IEEE control systems, 22(3), 5267.

Paul, B. G., and Vogl, C. R., 2011. Impacts of shrimp farming in Bangladesh: challenges and alternatives. Ocean and Coastal Management, 54(3), 201-211.

Pawlyn, M., 2011. Biomimicry in architecture (Vol. 15). London: Riba Publishing.

Peharda M, I Zupan, L Bavcevic, A Frankic and Klanjscek T., 2007. Growth and condition index of mussel Mytilus galloprovincialis in experimental integrated aquaculture. Aquaculture Research 38: 1714-1720.

Peña-Messina E, LR Martínez-Córdova, LF Bückle-Ramírez, M. Segovia-Quintero and Zertuche-González J., 2009. A preliminary evaluation of physiological filtration variables for Crassostrea corteziensis (Hertlein, 1951) and Anadara tuberculosa (Sowerby, 1833) in shrimp aquaculture effluents. Aquaculture Research 40: 17501758 .

Phillips M.J., 1995. Shrimp culture and the environment, pp. 37-62. In: Bagarinao TU, Flores EEC (eds) Towards Sustainable Aquaculture in Southeast Asia and Japan. SEAFDEC Aquaculture Department, Iloilo, Philippines.

Rawson M.V. Jr, C Chen, R Ji, M Zhu, D Wang, L Wang, C Yarish, JB Sullivan, T. Chopin and Carmona R., 2002. Understanding the interaction of extractive and fed aquaculture using ecosystem modeling. In: Stickney RR and JP McVey (eds). Responsible marine aquaculture, pp. 263-296. CABI Publishing, Oxon.

Romano, N., and Kumar, V., 2017. Vegetarian Shrimp: Pellet-free Shrimp Farming. World aquaculture, 37. 
Romano, N., and Kumar, V., 2017. Vegetarian Shrimp: Pellet-free Shrimp Farming. World Aquaculture, 37.

Samocha, T. M., Patnaik, S., Speed, M., Ali, A. M., Burger, J. M., Almeida, R. V., and Brock, D. L. (2007). Use of molasses as carbon source in limited discharge nursery and grow-out systems for Litopenaeus vannamei. Aquacultural Engineering, 36(2), 184-191.

Sandifer, P. A., and Hopkins, J. S., 1996. Conceptual design of a sustainable pondbased shrimp culture system. Aquacultural Engineering, 15(1), 41-52.

Senapin, S., Thaowbut, Y., Gangnonngiw, W., Chuchird, N., S. Sriurairatana and Flegel, T. W., 2010. Impact of yellow head virus outbreaks in the whiteleg shrimp, Penaeus vannamei (Boone), in Thailand. Journal of fish diseases, 33(5), 421-430.

Soto-Rodriguez, S. A., Gomez-Gil, B., LozanoOlvera, R., M. Betancourt-Lozano, and Morales-Covarrubias, M. S., 2015. Field and experimental evidence of Vibrio parahaemolyticus as the causative agent of acute hepatopancreatic necrosis disease of cultured shrimp (Litopenaeus vannamei) in Northwestern Mexico. Applied and environmental microbiology, 81(5), 16891699.

Thitamadee, S., Prachumwat, A., Srisala, J., Jaroenlak, P., Salachan, P. V., Sritunyalucksana, K., and Itsathitphaisarn, O., 2016. Review of current disease threats for cultivated penaeid shrimp in Asia. Aquaculture, 452, 69-87.

Thomas, N., Lucas, R., Bunting, P., Hardy, A., A. Rosenqvist and Simard, M. 2017. Distribution and drivers of global mangrove forest change, 1996-2010. PLoS one, 12(6), e0179302.

Thong, P. Y., 2014. Biofloc technology in shrimp farming: success and failure. Aquaculture Asia Pacific, 10(4), 13-16.

Tidwell, J. H., Coyle, S. D., Bright, L. A., A. VanArnum, and Weibel, C., 2003. The effects of size grading and length of nursery period on growth and population structure of freshwater prawns stocked in temperate zone ponds with added substrates. Aquaculture, 218(1-4), 209-218.

Tu, H. T., Silvestre, F., Bernard, A., Douny, C., Phuong, N. T., Tao, C. T., and Kestemont, P., 2008. Oxidative stress response of black tiger shrimp (Penaeus monodon) to enrofloxacin and to culture system. Aquaculture, 285(1-4), 244-248.

Tucker, C. S., and Hargreaves, J. A. (Eds.). (2009). Environmental best management practices for aquaculture. John Wiley and Sons.

Wasielesky Jr, W., Atwood, H., A. Stokes, and Browdy, C. L., 2006. Effect of natural production in a zero exchange suspended microbial floc based super-intensive culture system for white shrimp Litopenaeus vannamei. Aquaculture, 258(1-4), 396-403.

Weirich, C. R., Bratvold, D., C. L. Browdy, and Mcabee, B. J., 2003. Preliminary evaluation of emerging water treatment technologies for use in minimal exchange superintensive Pacific white shrimp Litopenaeus vannamei culture systems. In Aquaculture America Conference (pp. 318-332).

Wilber D.H, D. G. Clarke and Burlas M.H., 2006. Suspended sediment concentrations associated with a beach nourishment project on the northern coast of New Jersey. Journal of Coastal Research 22: 1035-1042

\section{How to cite this article:}

Srijit Chakravarty, Shivendra Kumar and Satya Prakash. 2018. Back to the Basics: Biomimicry in Shrimp Farming. Int.J.Curr.Microbiol.App.Sci. 7(05): 2172-2184.

doi: https://doi.org/10.20546/ijcmas.2018.705.253 